DOI: https://doi.org/10.32839/2304-5809/2019-1-65-73

UDC 008.2:303.832

Kovalchuk Olha, Masonkova Mariia

Ternopil National Economic University

\title{
CLIMATIC WEAPON - INSTRUMENT OF BIG POLITICS
}

Summary. The problem of global climate change, one of the major calls of modern civilization, is considered in the article. The analysis of arguments in relation to a hypothesis about technogenic influence on the global warming and anomalous natural phenomena is conducted. Documentary facts and data about possibility of development and application of secret technologies of artificial influence on the extreme natural phenomena are studied. An attempt to generalize information about existence and test of climatic weapon by the world supercountries, that they can secretly use with the aim of establishment of economic and political domination, is done.

Keywords: global climate change, anomalous cataclysms, climatic model, climatic weapon, world economic domination, political pressure.

Ковальчук О.Я., Масьонкова М.М.

Тернопільський національний економічний університет

\section{КЛІМАТИЧНІА ЗБРОЯ - ІНСТРУМЕНТ ВЕЛИКОЇ ПОЛІТИКИ}

Анотація. У статті розглянуто проблему глобальної зміни клімату - одного з найважливіших викликів сучасної цивілізації. Проведено аналіз аргументів щодо гіпотези про техногенний впливу на глобальне потепління та аномальні природні явища. Вивчено факти та дані стосовно можливості розробки та застосування таємних технологій штучного впливу на екстремальні природні явища. Зроблено спробу узагальнити інформацію про існування та випробування кліматичної зброї наддержавами світу, яку вони можуть таємно використовувати з метою встановлення економічного та політичного домінування.

Ключові слова: глобальна зміна клімату, аномальні катаклізми, кліматична модель, кліматична зброя, світове економічне панування, політичний тиск.

Tntroduction. Climate change, maybe, is the 1 most existencial problem of modern civilization. Ecological risks during the last years continue to prevail in the lists of global threats to humanity $[5 ; 12]$. The special disturbance is caused by the general swift increase of dynamics of cataclysms, that is observed in the last decades. According to the data of Global Risks Report 2019 of the World Economic Forum, ecological crisis, in particular, inability to solve the problem of climate change, are one of the most credible and biggest risks into that the world will run during a next decade. In 2018 there were record levels of charges through the extreme weather phenomena [22]. Not always these cataclysms are displays only of natural processes. A man all more often provokes the extreme weather phenomena, that results in terrible consequences not only for separate regions but also in a worldwide scale.

Today humanity entered the epoch of radical climatic changes, and this problem can not be examined as exceptionally scientific. It is a complex interdisciplinary problem that embraces social, political, economic and ecological aspects. There is a large risk of the insufficient understanding and underestimation of all factors and scales of influence of various space, geological and anthropogenic processes on the global climate change on Earth. These ecological problems have enormous consequences for our economy, society and politics.

Literature overview. Among modern scientists there is not a general idea about technologies ability to cardinally influence on natural calamities and existence of the so-called "climatic weapon". One ot them consider that it exists and it is tested a long ago. Other ones deny this fact categorically. The published scientific works with range of this problems in open access almost are not. Many years this problem was studied by American scientists, in particular Cliff Karnik [13], Elana Freeland [2] and Leonard Cole [1]. Materials about the use of climatic weapon, mainly, are secret. For wide public they are accessible only from the interview of soldiery and climatic experts, journalistic investigations or publications in magazines, technical reports and documentary videos $[10 ; 16 ; 17 ; 27 ; 28]$.

Selection of earlier unsolved parts of general issue. Problem of development, tests and application of climatic weapon by the world supercountries for economic and political influence on opponents is reaserched by separate soldiery analysts and experts on climate questions. Today none of the states officially admitted that it owns and anymore uses a seismic weapon. However, researches of these problems are extraordinarily actual in the conditions of threat of global ecocatastrophe.

Purpose. The aim of work is a study of questions of possibility of development and application of secret technologies of artificial influence on the extreme natural phenomena, what supercountries of the world can use as a secret weapon with the aim of establishment of the economic and political dominating.

Main Part. Never before in scientific circles there was not such clearly expressed disturbance about risks of climate change. Yet to the last time scientists reluctantly acknowledged the anthropogenic changes of climate as reasons of the special extreme weather phenomena. But already a few years they acknowledge this fact with a confidence $[5 ; 26]$. It became possible due to improved climatic models, increasing computers power, increase of ability of data interpretation, development of science about climatic changes [4, p. 86; 21]. A prob- 
lem of extreme climate change is one of major ones also for sustainable development of the world countries [4]. Special lecture of the Intergovernmental Panel on of Climate Change (IPCC), published in October, 2018 [20], proves this fact.

Facilities of weather manipulation are not new. Attempts to change a climate began much earlier, than the first cars appeared. In 1880 American general Ravel conducted a strange experiment. In a cloudy day he by means of air bullet heaved up in sky several hundreds kilogram of explosive and blew it up. From a powerful explosion clouds divided [28].

For the first time meteorological weapon was used during II world war. According to the data of historians, the German army experimented with influence of radio waves on an atmosphere. After their defeat all research materials were got by the USSR and USA. The scientists of these supercountries began to study how to tame obstinate nature. Americans was the first ones who successfully moved up in this question. In the war-time of Indo-chinese in autumn in 1966 they test under a vulture "secretly" new weapon. On verge of Vietnam and Laos during 5 years the American army regularly dispersed the iodide of silver in rain clouds, condensing moisture. It caused pouring rains [28].

Technologies of climate change by influence on an ionosphere began to be developed in 60th of past century. The department of defense of the USA carried out a grandiose experiment under the name of West Ford (Project West Ford). By means of three spaceships the half milliard of copper needles was delivered on the Earth orbit. They were evenly distributed in upper-airs and grew into space garbage that improves connection between satellites. But, at the same time, they absorb the additional amount of sunny heat and do a weather on Earth more sultry [26]. And it is only one of hundreds of global experiments on climate change.

At the same time first attempts of artificial influence on a climate and weather management were carried out in soldiery aims. The American and soviet specialists conducted experiments on influence of ionic sphere on an environment. An aim was the use of these developments as the weapon for an attack and defence. Scientists searched the critical points of typhoons, operating on that it is possible to change their trajectory of motion. For today the methods of action on atmospheric processes that can cause negative influence on territory of potential opponent are worked out. For example, considerable rise in temperature, drought or flood. So in the Vietnamese war-time in March in 1967 the USA conducted the grandiose operation "Papai" with the use of climatic weapon, 500 thousand persons suffered from that. In the riverhead of the river Mekong the American aviation dispersed dry ice and iodide of silver that entailed pouring thundershowers. The amount of precipitations increased in three times. Jungles grew into a bog.Among other ones the Path of Ho Shi Mine, that provide the south vietnam partisans with weapon and equipment, given by USSR, was washed out. For 5 years American whipped off 200 tone of silver on Vietnam. On present prices it is approximately $\$ 1,5$ milliards. At that time Pentagon have not undertake responsibility for raging of water element [9].
Only after interference of the UNO in 1977 Convention about prohibition of the use of environment change in hostile aims, artificial stimulation of earthquakes, kindling of arctic ice and climate change was accepted. However, declaration forbade a test, use and research only on territory of other states. On own territory prohibition did not operate. Between the USSR and USA there was a final secret agreement on stopping of developments in this sphere [27]. However, researches in this area proceed under the guise of scientific. New data ground to do supposition, that America and Russia entered into an unprecedented race that can make off "climatic war". They do attempts to use mortal force of nature (hurricanes, tsunamis, earthquakes and even sunny energy) as weapon in a fight for their mercantile interests [17].

So in February in 2013 naval forces of the USA reported that they had exposed to rays sky by high-frequency waves by means of the climatic setting of HAARP (High Frequency Active Auroral Research Program), located on Alaska. In the total on height of $170 \mathrm{~km}$ the anomalous phenomenon - socalled ionic cloud appeared. Power of all options of HAARP folds 1 milliard Watt. On an official version it investigates dynamic processes in the ionosphere of Earth. However, experts assert that the American army, beginning from 1997, secretly exposes to rays an atmosphere, changing a climate around the planet. HAARP is the military program of the USA. HAARP is the newest massive weapon, able remotedly to cause local droughts, thundershowers, cyclones and hurricanes, blow about thunderclouds, that a rain was not, to strengthen the mode of temperature, that snow or hail fell out [26]. However, regardless of presence of proofs, politics never acknowledge this fact.

A climatic weapon treats to the countries that own it, in a considerable sum. So the USA spent on setting HAARP $\$ 250$ milliard on a year. General charges on the American army on a year make $\$ 600$ milliard. American taxpayers expensively pay for possibility to change the world around the planet. Exactly the presence of climatic weapon helps the USA to impose own will to other countries [28].

Not only USA have such a threatening weapon. Soldiery experts assert that the USSR next to nuclear tests was actively conducted experiments with climatic weapon. Today to change a weather according own free will is possible for at least 5 countries in the world. It is countries that own the good satellite monitoring and carry out quality control after a meteo situation: the USA, Russia, China, Japan and EU. Climatic weapon a long ago became the inalienable instrument of large politics in all spheres [28]. Secret tests are conducted around the planet.

In August in 2010 on all Russia an anomalous heat that entailed 29 thousand forest fires was set. Moscow was wrapped by extraordinary smog. Carbon monoxide in 7 times exceeded maximum possible norm. The amount of deaths grew three times. Fires took away life more than 50 people, 2,5 thousand houses and almost million hectares of the forest were destroyed. Government estimated losses in an astronomic price - $\$ 300$ milliard [19].

While in Russia the protracted heat, for 3 thousand kilometres there were the biggest thunder- 
showers in all history of Pakistan. Water rose on $5,5 \mathrm{~m}$. An element took away life of 1,5 thousand people and destroyed 15 thousand houses. 20 million citizens remained without elementary facilities of existence. Experts assert that these anomalous weather phenomena were created exactly by setting HAARP. It is an answer for military aggression of Russia against Georgia. The USA applied a climatic weapon a few days prior to beginning of natural cataclysms. They launched satellites, the trajectory of flight of that had fully coincided with regions, where fires, floods and destructions were [28].

A climatic weapon can be more frightful than nuclear. It is able to cause Armageddon in any separately taken country. Soldiery developments in area of climate changes are secrets that have the greatest level of secrecy in all countries of the world. Climatic war is an alternative to nuclear. The computer model of nuclear winter showed, that there would be no winners. This climatic model became the important factor of worldwide policy.

Today the world is frightened by a new threat global warming. Climatologists assert that in the near future our world will be only heated. Natural changes can be sharp and catastrophic, but such situation was in history of Earth also before. As a climate is indissolubly related to politics, this problem has two constituents: cleanly scientific and economico-politic. Among scientists there is not a general idea about conception of the global warming. One assert that this process is caused by the natural vibrations of climate that repeatedly changed on the draught of history of Earth. Second group of scientists is sure that today's increase of temperature is the result of activity of humanity, in particular industrial production. If it wouldn't be sharply shorten, planet expects a catastrophe $[5 ; 28]$.

Our planet is sick. Something really takes place with a climate. The proof of it is a sharp increase of amount of natural catastrophes, in particular earthquakes, floods, tsunamis, hurricanes, typhoons. At a rise in temperature of climate his propensity to the extreme phenomena increases. In 2009 a world climatic summit took place in Copenhagen. As well as in science, opinions of leaders of different countries about the global warming were sharply divided [6]. The developed countries created the prosperity due to all humanity, throwing out all rabble in an atmosphere. Today they offer to other countries to shorten these extrass, not having regard to their necessities and problems.

Economic activity of man does the perceptible influence on a climate. However, such enormous amount of factors influences on it, that taking into account all of them is just impossible. Depending on data that is used in a climatic model, it is possible to get a desirable result. A hypothesis about the global warming can appear to the political orders. So for the USA Kyoto protocol about limitation of extrass in the atmosphere of greenhouse gases is not advantageous [27], as an observance of its terms will detain development of their economy.

The deficit of federal budget of the USA, that in 2018 fiscal year increased on 17\% and attained the record index of $\$ 779$ milliard, grows through the season of atlantic hurricanes. Removal of consequences of climatic catastrophes, that entailed considerable economic losses in the last few years, becomes the serious financial loading and causes the increase of deficit of budget. For a half year $\$ 140$ milliard is expended in these necessities, almost twice as much than it was distinguished to Ministry of internal safety. According to the data of Ministry of finance of the USA [Department of the Treasury] from 1980 to 2017 middly per year about six natural calamities were fixed, on liquidation of consequences of that more then $\$ 779$ milliard was needed. From 2013 to 2017 this index grew to 11,6 such cataclysms per year. To the 2018 USA grasped 11 weather emergency events, liquidation of consequences of that needs more then $\$ 1$ milliard [14].

Donald Trump declared recently, that he sceptically behaves to the lecture of the UNO about the climate changes and does not intend to spend the trillions of dollars on prevention of the global warming. The president of the USA decides to go out from the Parisian agreement primary objective of that is to slow the global warming [18]. At the same time Great Britain supports a hypothesis about fully anthropogenic influence on the climate change and pursues an economic policy, that is directed on maintenance of environment and reduction of hotbed extrass in an atmosphere. Countries are allies until an economy does not enter into contradiction, and each of the states lobbies own interests.

The problem of climate changes in actual fact is very important and while yet small studied. It gives an opportunity to use it for speculations both in politics and in an economy. The example of it is a well-known myth about influence of refrigerators that work on freon, on the increase of ozone holes in the stratosphere of Earth. This campaign was organized by the producers of refrigerators with other coldholders. Rumours about harm from aerosols became another marketing reception by means of that a choice is dictated to consumers. Ecologically conscious citizens force to elect more expensive and less comfortable in use hard deodorants, as believe that the fluidized gases negatively influence on an environment. The governments of leading countries do not hurry to refute numerous myths about so-called ecoproducts, in fact than more expensive commodities are bought by consumers, the more taxes they pay. These taxes, in turn, will be expended in the new types of climatic weapon. The researchers of climatic weapon assert that in pursuit after superprofits governments destroy whole cities, using natural cataclysms [28].

In August in 2005 the most destructive in history atlantic hurricane, Catarina, sweeps over the East coast of the USA. $80 \%$ of New Orlean city were flooded. The official amount of lost is approached to two thousand persons, about million remained without a roof above a head [11]. Researchers consider that one of most destructive hurricanes in history of the USA is created artificially by means of climatic weapon. They are sure that it, undoubtedly, was an action of HAARP. Scientists confirm, that such weather anomalies really can be provoked, exposing to rays an ionosphere from Earth. Except that, they noticed that hurricane Catarina and the tsunamis in 2004 caused surprisingly similar destructions [10].

New Orlean city in 2000 grew into the depressed region. It was inhabited by homeless Americans that lived generations in old wooden building and 
lived on a grant. The main source of acuestss in a region was strategically important port. However, it was built 300 years ago and needed expansion and modernisation. To build modern international port was impossible without the total taking of old quarters. Losses from hurricane Catarina are estimated in over $\$ 100$ milliard, however the senate of the USA distinguished for help to the injured states tenfold a less sum, and the lists of disappearing did not even fold [11].

Today climatic anomalies are fixed all over the world. The strangest thing is that a winter in the middle of summer takes place on a background of record high temperatures. In obedience to the supervisions of NASA, the last three years were the sultriest in all history of supervisions, and the temperature of Earth grows unceasingly. New ecology of the world is formed. All climate changes in general are anomalous. None of prognoses of climatologists is confirmed. From one side the promised global warming of planet lasts on the whole, and from other one there is anomalous icy cold in Europe [15].

So in April in 2017 Western, Central and East Europe was strucked by strong and unusual for this season frosts. Germany, Czech Republic, Austria, Ukraine, Poland and Switzerland were heaped up with snow. It was anomalously coldly in Europe also in May in 2019. Weather forecasting can not explain an atypical spring drop in temperature until now. In summer in 2017 in sunny Spain after an unendurable heat a temperature sharply fell down and frightful hurricane that was accompanied by snow and precipitations from the pieces of ice began. In February, in 2017 in Bolivia a 30-degree heat suddenly went down to $0{ }^{\circ} \mathrm{C}$. Country was covered by rains, hail and snow [28].

Environmentalists explain the anomalous climate changes by the extrass of greenhouse gases, that detain sunbeams and create the effect of hothouse on Earth [8]. However, experts have own shocking explanation of global catastrophes that terrorize the whole world. They assert that the armies of leading countries of the world test the socalled climatic weapon secretly. Today it is worked over at the level of experiments or practical works about artificial evocation of rains and influence on the centers of such meteorological actions, as hurricanes and typhoons.

Scientists conduct an analysis and modelling of climatic changes in the different regions of planet and assert that the separate natural phenomena can be created artificially. In opinion of analysts, a weather and climate today are the most effective weapon in secret war. Not by chance lectures about the climate problems for the president of the USA are prepared by CIA [28].

Powerful earthquake by magnitude in 9,3 points after Richter scale in the Indian ocean near an Sumatra island in 2004 provoked the biggest in history tsunami, that took away life of 300 thousand persons. According to official version a powerful 9 -ball earthquake happened in the middle of ocean and brought to appearance of enormous waves of $5 \mathrm{Mt}$ of trotyl equivalent. It twice as much than force of explosion of all bombs of II World war. From a destructive capacity of the fatal tsunami, caused by powerful waves, 14 countries suffered. A tsunami for a few seconds ravaged coast of Indonesia,
India, Sri Lanka and Thailand [24]. At the same time environmentalists and soldiery experts assert, that it and ten of other grandiose cataclysms were provoked artificially by means of the so-called seismic weapon. Tsunamis in Indonesia were caused by a very powerful submarine nuclear explosion, and scale earthquakes through this country, thousands of people perished in that, is the result of application or tests of climatic weapon. The height of wave exceeded 15 meters. Exactly this fact became an argument for world scientists for advancement of hypothesis, that an earthquake was created artificially. This military experiment is added to Pentagon. The fact that a tsunami did not brush against the nearby island located only after $100 \mathrm{Km}$ its epicenter became confirmation circumstance. Exactly on this island yet from 1973 there is the secret military American base. Experts assume that exactly there new types op weapon, including climatic, are developed. An economic aspect is also watched in this natural catastrophe. Researchers assert that the main target of tsunami was not Thailand, but nearby Indonesia the government of that ran into debt considerable sum of money to the western investors [28].

In September in 2017 after the destructive hurricanes "Harvey" and "Maria" USA tested a sledge-hammer blow of at once three new shattering hurricanes "Irma", "Catarina" and "Jose", that destroyed everything on the way and took away lifes of 77 people. The American budget sustained loss on $\$ 290$ milliard. Experts suspect, that a hurricane in Caribbean pestilence is original climatic revenge of Moscow for international approvals against it and anomalous heat that the USA arranged in Russia in 2010. These hurricanes rocked an oil price on a world exchange, that was substantially represented on the economy of the USA [23].

Specialists on armaments consider, that most global catastrophes are the result of tests of new standards of seismic weapon, and their amount grows swiftly. Technologies of creation of artificial cataclysms were developed by the leading nuclear states, in particular by the USA, Japan and Soviet Union, as a secret instrument of pressure on opponents. So Soviet Union used the Chornobyl' catastrophe, to compel the leading countries of the world to give up nuclear energy, that resulted in a world price increase on oil. By means of earthquake it is possible to prang any object, flood territory, leave a population without light, copula and others like that. A country that will own a seismic weapon will collect a contribution from the whole world.

In April, in 2017 the USA used a seismic weapon in war with terrorism - whipped off on the Afghanistan province of Nangarhar the biggest in the world non-nuclear weapon well-known as "Mother of all bombs". For development of this enormous bomb the American government spent over $\$ 300$ million. It was bargained that in mountain locality an explosive water-wave will appear and will entail the zone of continuous destructions on considerable distance from the epicentre of explosion. By this method the American army stopped coming of the islamic state that took almost all North of Iraq, from Baghdad to Erbil. A shock wave can destroy everything in the radius of $1,5 \mathrm{~km}$. By means of the 
system of the satellite aiming this bomb is able to strike aiming seismically unstable zones of mountain breeds and entail local earthquakes [7].

Exactly by this method in spring in 2017 Americans destroyed the unapproachable underground base of terrorists, Idil, located in the mountains of Afghanistan. However, Afghanistan politicians convinced, that under fight against the terrorists the USA boast before the world with the newest soldiery developments. They test the newest armament, to show own power to Russia and China [25].

At the same time specialists acknowledge possibility of realization of the "ecological acts" of terrorism, related to the climate change, provocation of earthquakes and eruption of volcanos. For today there is not exact determination of concept "ecological war", at the same time experts consider, that the leading countries of the world test a seismic weapon that causes global tsunamis and earthquakes around the planet regularly. Soldiery experts assert that on the bottom of world ocean there can be hundreds of the nuclear war-heads stopped up as early as times of cold war. They are ready to explode at any moment and entail ten of powerful tsunamis and earthquakes around the planet. The participants of the "Nuclear club" until now test nuclear weapon. So the earthquakes of 2018 in Israel and Japan were artificially created [28].

If to conduct the analysis of most natural calamities, it is possible to notice that they suddenly take place in countries that want to go out from under control of "elder brother" or began economically to grow. Snow-falls, typhoons, earthquakes, floods, pouring rains, nipping frosts, as though intentionally make successful countries to begin everything with beginning. Today the USA and Russia are accused of that they manage a weather. At the same time intestine climatic wars of modern supercountries bring considerable losses also to them.

Humanity all more often becomes the witnesses of "anger" of nature. Force with that it wipes off everything on the way strikes. In August in 2005 hurricane Catarina in the USA - about 2 thousand lost. May in 2008, Earthquake in the Chinese province Sichuan - not less than 100 thousand lost. In January in 2010 an earthquake on the island of Haiti brought over 200 thousand deaths. In March in 2011 earthquake and tsunami in Japan on a nuclear power plant in the Japanese prefecture Fukusima - over 20 thousand lost. All these typhoons, tsunamis, winds, are an experiment above elements and people. And after the screen of natural cataclysms there is the hidden fight for world economic domination [28].

In summer in 2013 China does a loud statement about possible rocket inflicting blows on the densely populated territories of the USA. For such sharp political statements as though there was not a single occasion. But in soldiery circles there was talk about the secret attacking China by the USA by means of climatic weapon. Through a month after these statements China suddenly experiences the biggest for the last 50 years flood and thundershowers. 6 million persons suffered. Suspicions of soldiery were not groundless - in hour to beginning of destructive flood in an atmosphere the strange phenomenon was fixed, look like Merry Dancers. It is interesting, that 5 years prior to it, when a pow- erful earthquake was brought down on the Chinese province of Sichuan, similarly a few hours prior to raging of element strange varicoloured clouds appeared in sky. Taiwan companions fixed the decline of closeness of ionosphere above China. All these factors testify that celestial Empire was attacked by means of new type weapon [28].

In III world war armies will militate by means of hail and tornados. Already today the front-rank countries of the world have possibilities of technogenic influence on certain regions and climatic terms on a certain period, for example, day, two, three et cetera. They will realize the format of change in the atmospheric layers of Earth. It is possible today to create artificially fog, cause a rain, do, that a hail fell out instead of rain. A geophysical weapon gives an opportunity to the enemy to remain unrecognizable and unpunished for years. Supercountries in future will continue experiments, but in the conditions of secrecy.

It is unknown, how the experiment of humanity with creation of artificial catastrophes will turn around. A seismic weapon can be dangerous after the scales for a planet on the whole. Our planet is literally pierced by underground dissidences that is stretched out on hundred kilometres. Pawning a powerful nuclear projectile in one of such break, it is possible to direct a shock wave in direction of potential enemy and cause a destructive earthquake on territory of its country. Thus the whole world will consider, that a duty natural cataclysm happened.

Specialists caution: climatic balance on our planet is an extremely unstable thing, and intentionally provoking cataclysms, humanity each time risks to prang this balance. Our planet is so fragile, that even a local catastrophe can result in global catastrophic humanitarian and ecological consequences.

Global climate change will entail the wave of mass migrations from drying up or freezing countries. Fight not only for energy resourses but also for territory or fresh water will become a reason of conflicts. In account of experts of the UNO, already today close one milliard of people in Africa, Middle Asia, China, India and on Middle East suffer from the lack of drinking-water. According to the statistical UNO data during the last 50 years about 500 international conflicts took place for water, 20 from that were full-scale wars. Even the largest in modern history terrorist organization, Idil, that controls 8 countries, takes only territories along the rivers [28].

Humanity engages in a self-destruction a long ago. The consequences of its activity became geological factor that can result in the self-destruction of Earth and humanity. Many climatic models that are built by the world scientists on the basis of the collected data envisage the further height of global temperature. Their scenarios are carried out not always and not in full. However, all of them testify that any interference with nature results in negative consequences. Today against the action of climatic weapon not a single habitant of planet is insured. In fact countries that are said to be pioneers in development of climatic weapon apply it even against own citizens.

Conclusions. The characteristic feature of climate changes is that their sentinel scales substantially exceed time of political life even of undemocratic leaders. Therefore it is a problem that in 
practice can be set aside, and all growing economic interests need to be satisfied immediately. In this situation it is enough difficult to attain a consensus.

In general seismic weapon, taking into account, that complex of processes that lie in its basis is not well-known, can be dangerous not only at regional or even continental level. It can be dangerous after the scale for a planet on the whole. The ecosystem of Earth may need millions of years, to set a shaky equilibrium and do possible existence of man. However, if humanity in future will behave as wreckers, our kind is doomed.

So main question remains open: all cataclysms that take place today are only "anger" of nature or not. Maybe, mass anomalous natural phenomena is just a war of supercountries that consider itself the "possessors of weather". Question of existence of climatic weapon in general also remains debatable.

\section{References:}

1. Cole L. Clouds of Secrecy: The Army's Germ Warfare Tests Over Populated Areas / L. Cole. - Washington DC: Rowman \& Littlefield, 1989. - 188 p.

2. Freeland E. Chemtrails, HAARP, and the Full Spectrum Dominance of Planet / E. Freeland. - Earth Port Townsend, Washington: Feral House, 2014. - 272 p.

3. Kovalchuk O. Mathematical modeling of sustainable development. Monograph / O. Kovalchuk. - Ternopil: TNEU, 2017. $-245 \mathrm{p}$.

4. Zerkalov D.V. Problems of sustainable development ecology. Monograph / D.V. Zerkalov. - K.: Osnova, 2013. - 430 p.

5. About the Problems and Consequences of Global Climate Change on Earth / AllatRa International Public Movement [Virtual Resource]. - Access Mode: https://allatra.org/.

6. Copenhagen climate change conference 2009 / The Duardian [Virtual Resource]. - Access Mode: https://www.theguardian.com/.

7. Everything you want to know about the 21,600 pound Mother of All Bombs dropped on ISIS in Afghanistan / The Economic Times [Virtual Resource]. - Access Mode: https://economictimes.indiatimes.com/articleshow/.

8. Explaining Extreme Events from a Climate Perspective / Amestos [Virtual Resource]. - Access Mode: https://www.ametsoc.org/.

9. Free Online Encyclopedia Wikipedia [Virtual Resource]. - Access Mode: https://wikipedia.org/.

10. Hurricane Katrina And 2004 Tsunami Caused Surprisingly Similar Destruction / Science Daily. - Princeton, New Jersey: Princeton University, Engineering School. [Virtual Resource]. - Access Mode: https://www.sciencedaily.com/.

11. Hurricane Katrina Statistics Fast Facts / CNN Library [Virtual Resource]. - Access Mode: https://edition.cnn.com.

12. Globalization 4.0 will help us tackle climate change. Here's how / World Economic Forum [Virtual Resource]. Access Mode: https://www.weforum.org/agenda/2019/.

13. Karnik C. Aerosol Crimes. Documentary video [Virtual Resource]. - Access Mode: https://www.youtube.com/.

14. Mnuchin And Mulvaney Release Joint Statement On Budget Results For Fiscal Year 2018 [Virtual Resource]. Access Mode: https://home.treasury.gov/.

15. NASA: Global Climat Change Vital Sign [Virtual Resource]. - Access Mode: https://climate.nasa.gov/.

16. Newspaper "Podrobnosti" [Virtual Resource]. - Access Mode: http://podrobnosti.ua/.

17. Obozrevatel.UA [Virtual Resource]. - Access Mode: https://www.obozrevatel.com/.

18. Official site TRAMP Ua [Virtual Resource]. - Access Mode: https://www.unian.ua/.

19. Russian newspaper RGRU [Virtual Resource]. - Access Mode: https://rg.ru/.

20. Special Report Global Warming of $1.5^{\circ} \mathrm{C}$ [Virtual Resource]. - Access Mode: https://www.ipcc.ch/.

21. The climate data factory https://theclimatedatafactory.com/.

22. The Global Risks Report 2019 / World Economic Forum [Virtual Resource]. - Access Mode: https://www.weforum.org/ reports/.

23. The stunning price tags for Hurricanes Harvey and Irma, explained / Vox [Virtual Resource]. - Access Mode: https://www.vox.com/.

24. Tsunami Sumatra 2004, Andaman Indonesia / SMS Tsunami Warnang [Virtual Resource]. - Access Mode: https://www.sms-tsunami-warning.com/.

25. U.S. Drops 'Mother of All Bombs' on ISIS Caves in Afghanistan / The New York Times [Virtual Resource]. Access Mode: https://www.nytimes.com/.

26. Ward W. Thirty Years of Space Communications Research and Development at Lincoln Laboratory / W. Ward, W. Floyd / Beyond the Ionosphere [Virtual Resource]. - Access Mode: https://history.nasa.gov/.

27. World Meteorological Organization [Virtual Resource]. - Access Mode: https://public.wmo.int/en.

28. YoutuBe [Virtual Resource]. - Access Mode: https://www.youtube.com/. 